\title{
SUPREME COURT'S JUDICIAL REVIEW AUTHORITY VS. CONSTITUTIONAL SUPREMACY IN THE MALDIVES: DOES THE CONSTITUTION STILL REIGN SUPREME?
}

\author{
Aminath Asfa Shafie* \\ Shamrahayu Abdul Aziz**
}

\begin{abstract}
The Supreme Court of Maldives is entrusted with the responsibility of upholding the supremacy of the Constitution. However, within the last ten years, the Supreme Court has been criticized for the Court's slow but steady progression to encroach on the powers of the parliament and as a result, undermine the supremacy of the Constitution. The objective and purpose of this article are to entail how the Supreme Court of Maldives had utilized its power to judicial review to undermine the supremacy of the Constitution over the years. This article uses library-based research. It analyses the principles of separation of powers, checks and balances and judicial review and how these principles are adopted in the Maldives. In addition, this article reviews and analyzes the decisions of the Supreme Court which are in contradiction to the Constitution. The findings of the article are evidential of how the Supreme Court had performed the constitutionally mandated legislative functions of the parliament through the Court's power to judicial review. The Supreme Court had established guidelines, regulated the rights and freedoms specified in the Constitution, and determined procedures. This article concludes by emphasizing the importance of exercising restraint when performing the constitutionally mandated functions of each branch, in order to ensure the supremacy of the Constitution as well the effective functioning of the three branches of government.
\end{abstract}

Keywords: Constitutional Supremacy, Judicial Review, Supreme Court, Separation of powers, Maldives

\footnotetext{
* Ph.D Student, Ahmad Ibrahim Kulliyyah of Laws, International Islamic University of Malaysia. Email: asfashafie@gmail.com.

** Associate Professor, Department of Islamic Law, Ahmad Ibrahim Kulliyyah of Laws, International Islamic University of Malaysia. Email: srahayu@iium.edu.my.
} 


\title{
KUASA SEMAKAN KEHAKIMAN OLEH MAHKAMAH AGUNG MELAWAN KETINGGIAN PERLEMBAGAAN DI MALDIVES: ADAKAH PERLEMBAGAAN MASIH LAGI UNDANG-UNDANG TERTINGGI?
}

\begin{abstract}
ABSTRAK
Mahkamah Agung Maldives diamanahkan untuk mempertahankan ketinggian Perlembagaan. Walaubagaimana pun, dalam sepuluh tahun kebelakangan ini terdapat kritikan terhadap Mahkamah Agung yang mengatakan bahawa terdapat usaha yang walaupun perlahan tetapi pasti dalam melemahkan ketinggian Perlembagaan di Maldives. Makalah ini bertujuan menjelaskan bagaimana Mahkamah Agung Maldives menggunakan kuasa semakan kehakiman untuk melemahkan ketinggian Perlembagaan. Makalah ini ditulis berasaskan kajian kepustakaan. Ia menganalisis penulisan mengenai konsep pengasingan kuasa, semak dan imbang dan kuasa semakan kehakiman, serta bagaimana semua prinsip ini diadaptasi di Maldives. Makalah ini turut menyemak dan menganalisis keputusan Mahkamah Agung yang bertentangan dengan peruntukan Perlembagaan. Penemuan makalah ini menjadi bukti bahawa Mahkamah Agung menggunakan kuasa semakan kehakiman bagi melaksanakan fungsi legislatif yang dianugerahkan oleh Perlembagaan. Mahkamah Agung membuat garis panduan bagi mengawal selia hak-hak dan kebebasan yang ditentukan dalam Perlembagaan dan tatacara perundangan yang tertentu. Makalah ini menyimpulkan betapa pentingnya bagi Mahkamah Agung mengekang penyalahgunaan kuasa dalam melaksanakan sebarang kuasa yang dimandatkan bagi menegakkan ketinggian Perlembagaan serta memastikan fungsi setiap organ kerajaan kekal berkesan.
\end{abstract}

Kata Kunci: Ketinggian Perlembagaan, Kuasa semakan kehakiman, Mahkamah Agung, pemisahan kuasa, Maldives

\section{INTRODUCTION}

This article reviews the main reason behind the calls for judicial reform in the Maldives. This includes decisions, which seek to undermine the supremacy of the Constitution by the Supreme Court. The Supreme Court of Maldives has been under review, locally and internationally, for encroaching on the powers of the legislature and assuming the legislative role of the parliament in many instances. In substantiating the arguments put forth in this article, the research made was based primarily on a 
thorough search and analysis of literature found therein. Through books and journal articles, the basis of the principle of separation of powers, checks and balances and judicial review are explored, as well as how these principles are adopted in the Maldives. Furthermore, decisions of the Supreme Court, published in the Court's website are also reviewed and analysed against the provisions of the Constitution from which those decisions contradict. This article finds that the Supreme Court, the selfassumed guardian of the Constitution, is the one that is also undermining the supremacy of the Constitution. By reviewing the decisions of the Supreme Court in this article, it becomes evident that through the Court's power of judicial review, the Supreme Court is assuming the legislative role of parliament.

For instance, this article finds that in 2012, although the Constitution specifically stated that the authority to regulate the rights and freedoms specified in Chapter Two of the Constitution is vested unto the parliament, the Supreme Court established a guideline regulating the freedoms of expression, association, and assembly. Furthermore, in 2013, despite the Constitution specifying that the Elections Commission (EC) is an independent institution, which functions as provided in the Constitution and laws enacted by the parliament, the Supreme Court established guidelines regulating how the EC should conduct the presidential elections. This article also finds that in 2014, when the EC refused to comply with the previous decision of the Supreme Court, the Court initiated a Suo Motu case against the members of the EC, ordered them to enforce the guidelines determined by the Supreme Court and dismissed both the Commissioner and Deputy Commissioner of the EC from office, despite the Constitution specifying that it is the parliament that has the sole authority to remove members of the EC from office.

And, in 2015, another Suo Motu case was initiated by the Supreme Court, this time against the Human Rights Commission of Maldives (HRCM). In this case, the Supreme Court once again established guidelines for the HRCM to adhere to when performing its constitutionally mandated functions of promoting and protecting human rights in the Maldives. HRCM is also an independent institution, which functions are provided in the Constitution and laws enacted by the parliament. Furthermore, this article finds that, in 2015, even though the Supreme Court does not have the authority to amend any inconsistencies within laws, the Supreme Court declared some provisions of the laws 
invalid by determining the appeal period, which was predetermined by those laws.

In 2017, the Supreme Court declared that the Court itself would determine the validity of any no-confidence vote taken by the parliament against members of the Cabinet, the President, the Vice President, Judges, members of the Elections Commission, members of the Civil Service Commission, members of the Human Rights Commission, members of the Anti-Corruption Commission, Auditor General and the Prosecutor General. This decision by the Supreme Court limited the constitutionally vested power of the parliament to take no-confidence votes. Also, in 2018, the Supreme Court issued a Court Order limiting the Judicial Service Commission (JSC)'s constitutionally vested power to appoint Judges to Courts of law and the power to investigate and review matters filed against Judges. The Constitution specifically states that the authority to regulate the functions, mandates, powers and such of the JSC is vested unto the parliament.

Therefore, in this article, it becomes apparent how the Supreme Court of Maldives has been undermining the supremacy of the Constitution, by encroaching on the constitutionally mandated functions of the parliament, during the last ten years.

\section{BRIEF CONSTITUTIONAL HISTORY OF MALDIVES}

In the long constitutional history of the island nation of Maldives, the first Constitution was enacted in 1932. Prior to this, the Maldivian people were accustomed to living without any written constitution. Therefore, the first Constitution of Maldives was met with fierce resistance from the public. As a result, the first Constitution of Maldives was soon declared a failure by the people. Maldivians came out onto the streets in protest and demanded the Sultan to hand them the Constitution. Because of the demands of the people, the Sultan ordered Prime Minister Mohamed Fareed to hand the first Constitution to the people; that Constitution was ripped apart by the people. ${ }^{1}$ Although it was ripped apart by the people,

\footnotetext{
${ }^{1}$ Aishath Azra, "Furathama Qaanoon Asaaseege Sababun Dhivehi Raajjeyge Siyaasee Masrahah Ai Badhaluthah", (Research Report, Maldives College of Higher Education, 2010).
} 
the first Constitution of Maldives was not repealed. ${ }^{2}$ It was finally amended in 1934, when the Maldivians decided to give another chance to being ruled by a Constitution. ${ }^{3}$

Since then, there have been a number of Constitutions, most of which had been amended several times. In 2004, President Maumoon Abdul Qayyoom assembled the People's Special Majlis, the upper house of the bicameral parliament of Maldives (it was dissolved after the completion of the Constitution), to reform the Constitution. The People's Special Majlis worked on the first ever, democratic Constitution of the Republic of Maldives, as per the democratic reform agenda of President Maumoon Abdul Qayyoom. This democratic Constitution was ratified in 2008, which established and separated the three branches of government.

\section{SEPARATION OF POWERS: THE EXECUTIVE, LEGISLATIVE AND JUDICIARY}

In his book, 'Constitutionalism and the Separation of Powers', M.C.J. Vile defines the 'pure doctrine' of separation of powers. The 'pure doctrine' of separation of powers claims that the three branches of government should be completely separate from its functions to even its personnel. ${ }^{4}$ However, even Vile himself argued that the 'pure doctrine' approach to the separation of powers would not lead to an effective functioning of the government. ${ }^{5}$ This could be the reason why there are no modern democracies, which exercise a complete separation of powers, as advocated by M.C.J. Vile. Mainly, in constitutional democracies the three branches of government are separate to a degree; a system of checks and balances are put in place, through which each branch of government

\footnotetext{
${ }^{2}$ In the Preamble of the Constitution of Maldives, 1934 ( $1{ }^{\text {st }}$ Amendment to the $1^{\text {st }}$ Constitution of Maldives, 1932), it states that it was decided to amend certain articles of the Constitution. Therefore, the Constitution of Maldives 1932 was not repealed but amended in 1934.

${ }^{3}$ Constitution of Maldives, 1934 ( $1^{\text {st }}$ Amendment to the $1^{\text {st }}$ Constitution of Maldives, 1932), Preamble, 02.

${ }^{4}$ M. J. C. Vile, Constitutionalism and the Separation of Powers, (Indianapolis: Liberty Fund, Inc, Second edn., 1998), 14.

5 Roger Masterman, The Separation of Powers in the Contemporary Constitution: Judicial Competence and Independence in the United Kingdom, (New York: Cambridge University Press, 2010), 11.
} 
supervises the actions of the other branches of government to hold them accountable. The goals which the principle of separation of powers sets out to achieve are imperative to the efficient functioning of the government and rule of law; resisting abuse of power by the branches of government, avoiding the concentration of power in one branch of government, ensuring the independence of the branches of government and the promoting respect for the rule of law. ${ }^{6}$

The Maldivian approach to separation of powers is quite similar to the American approach. The U.S. Constitution establishes three separate branches of government; the executive, legislative and judiciary. The responsibilities, duties, and functions of these branches are then determined and compartmentalized within the constitutional structure. What each branch can and cannot do is predetermined in the U.S. Constitution. Furthermore, the U.S. Constitution vests the judiciary with the most important role of all; ensuring that neither branch of government is encroaching on the jurisdiction of one another. ${ }^{7}$

Montesquieu's interpretation of the principle of separation of powers takes this principle as a safeguard to ensure liberty to the three branches of government. Montesquieu believed that if the three branches of government, the legislative, the executive and the judiciary, are not separated from each other, the powers of those branches of government would be subjected to arbitrary control. While Montesquieu advocated against the concentration of power within just one branch of government, it was John Locke who improved that interpretation of the principle of separation of powers by advocating that the principle also has the ability to ensure efficient functioning of the government. ${ }^{8}$ Montesquieu's and John Locke's interpretation of the principle of separation of powers is reflected in the Constitution of the Republic of Maldives.

The three branches of government in the Maldives, the legislative, the executive, and the judiciary, are separated to ensure their independence

\footnotetext{
${ }^{6}$ Aileen Kavanagh, "The Constitutional Separation of Powers" in Philosophical Foundations of Constitutional Law, edited by David Dyzenhaus and Malcolm Thorburn (Oxford: Oxford University Press, 2016), 221-223.

${ }^{7}$ Debra Perlin, "Marbury on the Thames: Separation of Powers in the United Kingdom's Nascent Supreme Court", NCJ Int'l L., vol. 42 (2016): 197.

${ }^{8}$ Masterman, The Separation of Powers in the Contemporary Constitution: Judicial Competence and Independence in the United Kingdom, 13-14.
} 
from one another and it also ensures the efficient functioning of the government. All legislative powers are vested in the parliament of the Maldives, the People's Majlis. ${ }^{9}$ The Constitution, while specifying the legislative and oversight functions of the parliament, provides the parliament with the autonomous powers to self-regulate. ${ }^{10}$ The executive power is vested in the President of Maldives. ${ }^{11}$ The President is the Head of State, Head of Government and the Commander in Chief. ${ }^{12}$ The powers of the President and the functions of the President, as the Head of the State, are specified in the Constitution. For instance, the President supervises the efficient and harmonious functioning of the Government, ${ }^{13}$ promotes the rule of law and protects the rights and freedoms of all people, ${ }^{14}$ and formulates fundamental policies of the State. ${ }^{15}$ The President also determines, conducts and oversees the foreign policy of the country. ${ }^{16}$ The judicial power is vested in the courts of law in the Maldives. ${ }^{17}$ The Supreme Court is the highest authority in administering justice in the Maldives, and the Chief Justice of the Supreme Court is the highest authority in the Supreme Court as well as the entire judiciary of Maldives. ${ }^{18}$

The Constitution ensures the independence and the impartiality of the judiciary by forbidding any government or public official or any person from interfering with or influencing the functions of the Courts of law in the Maldives. ${ }^{19}$ The judges of the Courts of law are only subject to the Constitution and the law. ${ }^{20}$ The Constitution provides the parliament with the authority to enact legislation regarding the establishment, composition and various other aspects of administering justice, while the judiciary is given the authority to regulate the procedures of the Court's

\footnotetext{
${ }^{9}$ Constitution of the Republic of Maldives 2008, Article 5.

${ }^{10}$ Ibid., Article 88 (a).

${ }^{11}$ Ibid., Article 6.

12 Ibid., Article 106 (b).

13 Ibid., Article 115 (b).

${ }^{14}$ Ibid., Article 115 (c).

${ }^{15}$ Ibid., Article 115 (e).

${ }^{16}$ Ibid., Article 115 (j).

${ }^{17}$ Ibid., Article 7.

18 Ibid., Article 141 (b).

${ }^{19}$ Ibid., Article 141 (c).

${ }^{20}$ Ibid., Article 142.
} 
in accordance with the legislation enacted by the parliament and the interests of justice. ${ }^{21}$

Since a harmonious relationship between the executive and the legislative is essential, the roles of the executive and the legislative are, for the most part, intertwined. To ensure the democratic rule, most of the executive's functions require the approval of the parliament, while all legislation enacted by the parliament require the Presidential assent in order to become a law. The executive enjoys making and enforcing policies to govern, as well as the enforcement of the Constitution, the legislation enacted by the parliament and the decisions of the Judiciary.

\section{SUPREMACY OF THE CONSTITUTION}

The three branches of government are neither above the Constitution, nor superior to one another. Mechanisms are set in place in the Constitution to ensure the supremacy of the Constitution, as well as the effective functioning of these branches of government, as provided in the Constitution. For instance, the Constitution ensures the supremacy of the Constitution itself through Article 268 of the Constitution, also known as the supremacy clause. Firstly, the Article states that any legislation or any conduct that contradicts the Constitution is void. The supremacy clause of the Constitution also imposes responsibilities on the branches of government. The legislature must enact legislation in accordance with the Constitution. The executive must enforce legislation and orders in accordance with the Constitution. And the judiciary must ensure the supremacy of the Constitution by taking the Constitution as a yardstick when interpreting legislation and determining the constitutional validity of legislation. ${ }^{22}$

Therefore, it is evident, any legislation and or any regulation inconsistent with the Constitution has no effect and is void. Furthermore, it is clear that all obligations imposed by the Constitution on the branches of government as well as the independent institutions and independent officers must be fulfilled, as specified in the Constitution. In order to ensure the supremacy of the Constitution, the Constitution grants the

\footnotetext{
${ }^{21}$ Ibid., Article 156.

${ }^{22}$ Ibid., Article 268
} 
High Court and the Supreme Court the authority to conduct judicial reviews.

\section{THE SUPREME COURT OF MALDIVES}

In accordance with the Constitution, on $18^{\text {th }}$ September 2008, the Supreme Court of Maldives was established. As the highest authority in administering justice in the Maldives, the Supreme Court in many of its decisions has assumed the role of the 'guardian of the Constitution'. ${ }^{23}$

The Constitution specifies that the Supreme Court's bench must consist of the Chief Justice and an odd number of Judges provided by law. ${ }^{24}$ The composition of the Supreme Court had been subjected to the amendments brought to the Judicature Act (Act No.: 22 of 2010) by the parliament; initially, it was a total of five Judges, however, in 2010 the composition was raised to seven only to be reverted back to five Judges in 2014. So, therefore, as of 2018, there are five Judges on the Supreme Court bench including the Chief Justice..$^{25}$

The Chief Justice ${ }^{26}$ and the other Judges of the Supreme Court are appointed to the position by the President; with the consultation of the Judicial Service Commission (JSC), and after having received confirmation from the parliament. ${ }^{27}$ The Chief Justice, as the head of the Supreme Court and the highest authority in the Judiciary. He oversees the operation and functioning of the administration of the Supreme Court and the Court itself. ${ }^{28}$

The Regulation of the Supreme Court specifies that when resolving disputes, the Supreme Court must abide by and consider the tenets of Shari'ah, the Constitution of the Republic of the Maldives and the

\footnotetext{
23 Supreme Court of Maldives, "Tha'aaraf", <http://www.supremecourt.gov.mv/about.php?title=history> (accessed 6 June, 2018).

${ }^{24}$ Constitution... 2008, Article 145 (a).

25 Tha'aaraf.

${ }^{26}$ Constitution... 2008, Article 147.

${ }^{27}$ Ibid., Article 148 (a).

${ }^{28}$ Judicature Act of Maldives, 2010 (Act No. 22 of 2010), Article 4 (d).
} 
subsequent laws and regulations. ${ }^{29}$ The Supreme Court also has the prerogative authority to administer and maintain justice, as well as the authority to take preventive measures to ensure the autonomy and impartiality of the judicial system. ${ }^{30}$

As the highest authority in the judiciary, the Supreme Court has the inherent authority to resolve constitutional issues, which may lead to a legal vacuum, as well as the authority to resolve disputes between the branches of government regarding the interpretation of the Constitution. ${ }^{31}$ The Supreme Court also has the authority to inquire into matters deliberated in the High Court, ${ }^{32}$ as well the authority to provide answers to questions of law regarding any matter, the interpretation of the Constitution and the constitutionality of legislation, submitted to the Supreme Court by a resolution passed by the parliament. ${ }^{33}$

\section{AUTHORITY TO JUDICIAL REVIEW}

The constitutional doctrine of judicial review grants the judiciary the power to invalidate legislation, or executive orders and actions, after determining that it is unconstitutional. Some Constitutional theorists view that the doctrine of judicial review is anti-democratic, because through the power to judicial review, appointed judges of Courts are striking down legislation enacted by elected representatives of the people. However, it could also be perceived that through judicial review, courts are ensuring that the government stays within the boundaries of the Constitution. ${ }^{34}$

There are two types of judicial review adopted by countries; a weak judicial review and a strong judicial review. In a weak judicial review, the judiciary is only given the power to interpret legislation. Whereas in a strong judicial review, the judiciary is given the power to interpret, review and declare invalid legislations that are in contradiction with the

\footnotetext{
${ }^{29}$ Regulation of the Supreme Court, Supreme Court of Maldives, Article 11.

${ }^{30}$ Judicature..., Article 22 (a).

${ }^{31}$ Ibid., Article 11.

${ }^{32}$ Ibid., 12.

${ }^{33}$ Ibid., 13, see also; Constitution... 2008, Article 95.

${ }^{34}$ David S. Law, "A Theory of Judicial Power and Judicial Review", The Georgetown Law Journal Vol. 97, 2009, 723.
} 
Constitution. ${ }^{35}$ In the Maldives, both of these versions of judicial review are adopted. While the Supreme Court and the High Court are given the jurisdiction of strong judicial review, all the other Courts of law are given the jurisdiction of weak judicial review.

Therefore, all Courts of law are given the power to interpret legislation and regulations. However, only the Supreme Court and the High Court has the power to determine the constitutional validity of any legislation or regulation. ${ }^{36}$ The Supreme Court is, though, the final authority on determining matters regarding the interpretation of the Constitution, interpretation of legislation or any other matter dealt with by any Court of law. ${ }^{37}$ Because the Supreme Court is at the top of the hierarchy of the judiciary, all other Courts of law in the Maldives, as well as the legislature and the executive, are bound by law to obey and conform to the decisions of the Supreme Court. ${ }^{38}$

Hence, the Courts of law in the Maldives, the executive, and the parliament, as well as the independent officers, government institutions and government officers and the security services of the Maldives has to conform to all the rulings, the Court Orders and the decisions of the Supreme Court, issued regarding any matter.

The constitutionally vested authority to interpret legislation and declare the constitutionality of the legislation, does not, however, give the Supreme Court or the High Court the power to legislate, amend or repeal legislation. The Constitution; regarding the constitutionality of legislation and regulations, specifies that the Supreme Court and the High Court only has the power to declare invalid any legislation, regulation, executive order, decision or action of any person or body performing a public function that is inconsistent with the Constitution, and to the extent of that inconsistency. Therefore, if there is a provision in the legislation that is inconsistent with the Constitution, the Supreme Court and the High Court can only declare that provision void. Both the

35 Bernadette Sangmeister, "Judicial Review of Legislation in the UK: Fundamental Common Law Principles as "Constitutional Principles" Limiting the Sovereignty of Parliament?" Research Paper, Faculty of Law, Victoria University of Wellington, 2013, 8.

${ }^{36}$ Constitution... 2008, Article 143 (a).

${ }^{37}$ Ibid., Article 145 (c).

${ }^{38}$ Judicature..., Article 20 (a) and (b). 
Supreme Court and the High Court does not have the constitutional jurisdiction to declare the whole legislation invalid. The Constitution also grants the Supreme Court and the High Court with the discretionary power to allow the relevant authority to correct any inconsistencies found in the legislation, regulation, executive order or action of any person or body performing a public function. Therefore, the scope of the Supreme Court and the High Court's power to judicial review is that neither the Supreme Court nor the High Court has the power to amend an inconsistency, but only the power to declare the inconsistency invalid. ${ }^{39}$

Therefore, it is evident that the Supreme Court and the High Court, similar to the Supreme Court of the United States (SCOTUS), has the power to review not only laws enacted by the parliament but also regulations, orders and decisions or actions of any person or body performing a public function, i.e. decisions and actions of the government and its institutions as well the decisions and actions of the independent officers and independent institution. However, the SCOTUS took onto itself the power to interpret, review and invalidate legislation, executive orders and acts through the decision in the case Marbury $v$. Madison in $1803 .{ }^{40}$ And with the power of judicial review, the U.S. Supreme Court had been playing a huge role in the political and legal systems of America; the Court has been imposing limitations on the constitutionally vested powers of both the executive and the legislative bodies. ${ }^{41}$ Whereas it is the Constitution of the Maldives that gives the Supreme Court and the High Court of Maldives the power of judicial review. And the scope of the power of the judiciary to conduct judicial review is also determined by the Constitution.

While the provisions of the Constitution regarding the Court's power to judicial review are clear and precise, some of it is open to interpretation. For example, the usage of the phrase 'make any order that is just and equitable,' in Article 144 (b) of the Constitution, stipulates

${ }^{39}$ Constitution... 2008, Article 144 (c).

40 Perlin, Marbury on the Thames: Separation of Powers in the United Kingdom's Nascent Supreme Court, 198.

41 Ilya Somin, "The Supreme Court of the United States: Promoting Centralization More Than State Autonomy" in Courts in Federal Countries: Federalists or Unitarists?, edited by Nicholas Aroney and John Kincaid (Toronto: University of Toronto Press, 2017), 444. 
that the Court does have the discretion to make any order, as long as it is just and equitable and it does not have to be limited to the orders specified in Article 144 (b) of the Constitution. Defining and determining what is 'just and equitable' is also left to the discretion of the Supreme Court. Therefore, the decisions of the Supreme Court entails that the Supreme Court does not limit its judicial review authority to Article 144 of the Constitution, but creates its own scope of the judicial review authority. The result is the Supreme Court encroaches upon the powers of the other branches of government and undermining the supremacy of the Constitution.

The ambiguity of such provisions fuels political conflicts between the branches of government. ${ }^{42}$ And it is these linguistic loopholes and ambiguities that the Supreme Court proceeds to exploit in order to establish its superiority over the constitutionally established mandate.

\section{ESTABLISHING GUIDELINES}

Since its establishment in 2008, the Supreme Court has been slowly but steadily testing the supremacy of the Constitution, and utilizing the Court's power of judicial review to encroach upon the powers and functions of the parliament. The Supreme Court, through its interpretation of the Constitution and legislation, as well as through its power to conduct judicial review, paid no attention to the frameworks set forth in the Constitution. There were various decisions in which the Supreme Court imposed limitations on the constitutionally vested power of the parliament to perform its constitutionally mandated oversight functions. There were also decisions in which the Supreme Court was also seen establishing guidelines, despite the existing constitutional provisions, encroaching and overstepping the set boundaries of the legislative authority of the parliament.

For instance, the power to regulate and or limit any right or freedom specified in Chapter 2 of the Constitution by enacting legislation is constitutionally mandated function of the parliament. Article 16 (a) of the Constitution states that the Constitution that the parliament has the power to limit rights and freedoms specified in Chapter 2 of the Constitution.

${ }^{42}$ Matthew E. Glassman, Separation of Powers: An Overview, (2016), 13. 
Furthermore, the Article states that the parliament can only limit those rights and freedoms in a manner that is in conformity to the Constitution and to an extent that can be justified in a free and fair democratic society. ${ }^{43}$

When the parliament regulates and imposes limitations on the rights and freedoms specified in Chapter 2 of the Constitution, the Courts are constitutionally mandated to ensure that the limitations imposed on the rights and freedoms by the parliament are imposed as provided in the Constitution. ${ }^{44}$ The Constitution, however, does not provide any Court of law with the authority to limit any right or freedom specified in Chapter 2 of the Constitution. However, in 2012, the Supreme Court determined the following case, in contradiction with Article 16 (a) of the Constitution. In the following case, the Supreme Court regulates some of the rights and freedoms specified in Chapter 2 of the Constitution, even though the Court does not have the mandate to do so.

Due to the political climate of Maldives, in 2012, the Attorney General submitted a petition to the Supreme Court, requesting the interpretation of Articles 27, 30 and 32 of the Constitution. Article 27 of the Constitution provides freedom of expression, while Article 30 of the Constitution provides the freedom to form political parties, associations and societies, and Article 32 of the Constitution provides the freedom to assembly. In this petition, the Attorney General stated that certain acts, such as the act of defaming the reputation and dignity of people by spreading false information, aggressive demands for certain people to be lynched or attacked, and many other such acts conducted in the name of political activism are not acceptable in a civilized society, and therefore are not conducted within the boundaries set forth in the Constitution. The Attorney General requested the Supreme Court to interpret Articles 27, 30 and 32 of the Constitution, to determine such acts are in fact, conducted beyond the boundaries set forth in the Constitution.

Despite the constitutional provision stating that the rights and freedoms specified in Chapter 2 of the Constitution can only be limited by legislation enacted by the parliament, the Supreme Court through its interpretation of Article 27, 30 and 32 of the Constitution established a

${ }^{43}$ Constitution of Maldives, 2008, Article 16 (a).

${ }^{44}$ Ibid., Article 16 (c). 
guideline. This guideline established by the Supreme Court determined certain acts, which are disruptive to maintain public order and established that any individual or body conducting such acts must be investigated and brought to justice. Establishing such a guideline regulating what people can and cannot do when exercising their constitutionally given rights is the Supreme Court performing the constitutionally mandated legislative function of the parliament.

The Supreme Court establishing a guideline through its authority to interpret was dissented from by Supreme Court Justice Ahmed Muthasim Adnan. Justice Ahmed Muthasim Adnan expressed in his obiter dictum that even though the acts mentioned by the Attorney General are atrocious and alarming, to say the least, the Supreme Court does not have the authority to regulate nor limit the rights and freedoms specified in Chapter 2 of the Constitution. Supreme Court Justice Ahmed Muthasim Adnan mentioned that it is evident from Article 16 (a) of the Constitution that it is an absolute power of the parliament as the legislative body to limit the right and freedoms specified in the Constitution while the role of the Judiciary is to ensure that the rights and freedoms limited by the parliament are limited in accordance with the Constitution.

In his obiter dictum, Supreme Court Justice Ahmed Muthasim Adnan explained that even though the Attorney General requested the Supreme Court to establish a guideline defining the boundaries of the rights and freedoms, in the petition to interpret Article 27, 30 and 32 of the Constitution, the Supreme Court does not have the jurisdiction to establish such a guideline, and also does not have the authority to establish the boundaries of the rights and freedoms in Chapter 2 of the Constitution. Supreme Court Justice Ahmed Muthasim Adnan also expressed that in accordance with the principle of separation of powers, the Judiciary must not surpass the powers vested unto it from the Constitution and seize or infringe on the constitutionally vested powers of the other branches of government. ${ }^{45}$

${ }^{45}$ Petition to Supreme Court for Interpretation by Attorney General's Office, [2012], Supreme Court of Maldives, (Case No.: 2012/SC-C/24) 04 ${ }^{\text {th }}$ December 2012. 
Regardless, this ruling by the Supreme Court was enforced by the relevant authorities. The Supreme Court seemingly had gained a foothold and was not showing any sign of restraint.

\section{AUTHORITY TO SUO MOTU}

In Suo Motu cases, the Court has the power to initiate, investigate, and determine the decision on a matter in its jurisdiction, without a petitioner submitting the matter to the Court. ${ }^{46}$ Neither the Constitution of Maldives nor any subsequent legislation or regulations grant any Court of law in the Maldives to initiate Suo Motu cases.

However, in 2014, the Supreme Court issued a regulation, granting itself the authority to initiate Suo Motu cases. Even though the Constitution does not specifically grant the Supreme Court the authority to "investigate, prosecute and adjudicate any matter" on its own initiative, ${ }^{47}$ the Judicature Act specifies the jurisdiction of the Supreme Court in its own right, which provides the Supreme Court, in accordance with the law, the authority to administer justice and prevent the exploitation of the judicial system through its own initiative. ${ }^{48}$ This jurisdiction was determined by the Judicature Act (Act No.: 22 of 2010), a piece of legislation enacted by the parliament; the very body constitutionally vested with the authority to determine the administration, trial and appellate jurisdiction and trial procedures of the Supreme Court or any Court of law. ${ }^{49}$ Supreme Court also justified the issuing of the regulation providing the Supreme Court the authority to initiate Suo Motu cases, by citing provisions of the Constitution that provided the Supreme

${ }^{46}$ Shoaib A. Ghias, "Miscarriage of Chief Justice" in Fates of Political Liberalism in the British Post-Colony: The Politics of the Legal Complex, edited by Terence C. Halliday, Lucien Karpik, and Malcolm M. Feeley (Cambridge University Press, 2012), 345.

${ }^{47}$ International Commission of Jurists, "Justice Adrift: Rule of Law and Political Crisis in the Maldives- A fact-finding Mission Report", <https://www.icj.org/wp-content/uploads/2015/08/Maldives-Justice-AdriftRule-of-Law-Publications-fact-finding-report-2015-ENG.pdf> (accessed 25 September, 2018).

${ }^{48}$ Judicature Act., Article 22.

${ }^{49}$ Constitution of Maldives, 2008, Article 155. 
Court with the authority to adjudicate on constitutional matters, ${ }^{50}$ the authority to self-regulate, and the provisions of the Judicature Act that provided the Supreme Court with the authority to adjudicate on all matters as the highest authority for administering justice in Maldives ${ }^{51}$ and the authority to adjudicate on constitutional issues which concerns public interest. ${ }^{52}$

Soon after the issuing of this regulation, the Supreme Court initiated its very first Suo Motu case, against the Elections Commission (EC). In this case, the Supreme Court stated that the EC had willfully disregarded and disobeyed the Supreme Court ruling issued in Jumhooree Party $v$. Elections Commission [2013], in which the Supreme Court established guidelines for the EC to adhere to in holding the presidential elections. ${ }^{53}$ Furthermore, the Supreme Court expressed that the members of the EC had publicly on numerous occasions, criticized the authority of the Supreme Court to issue such guidelines and had wilfully refused to comply with the orders of the Supreme Court. As a result, the Supreme Court ordered the EC to enforce the guidelines set forth in Jumhooree Party v. Elections Commission [2013] and dismissed both the Commissioner and Deputy Commissioner of the EC from office and issued a suspended jail sentence on them on the grounds of contempt of court. ${ }^{54}$

$\mathrm{EC}$ is an independent institution, the powers, and functions of which are determined by the Constitution and legislation enacted by the parliament. The functions, responsibilities, powers, and mandate of the EC have to be determined by legislation enacted by the parliament. In this legislation, the parliament also has the power to specify the qualification and ethical standards of the members of the EC. ${ }^{55}$

${ }^{50}$ Ibid., Article 144.

${ }^{51}$ Judicature Act, Article 9 (f).

52 Ibid., Article 11 (a) (3).

53 Jumhooree Party, v. Elections Commission [2013], Supreme Court of Maldives, (Case No.: 2013/SC-C/42), 07 October 2013.

${ }^{54}$ Suo Motu Case Against the Elections Commission [2014], Supreme Court of Maldives, (Case No.: 2014/SC-SM/15), Supreme Court of Maldives, 12 February 2014.

${ }^{55}$ Constitution of Maldives, 2008, Article 167 (b) and (c). 
Therefore, it is evident from the provisions of the Constitution that the Supreme Court, nor any Court of law, has the authority to determine guidelines on how the EC should function. It is a constitutionally vested authority of the parliament to legislate regarding any matter, including the EC and the elections held in the Maldives.

Although the Supreme Court has the discretionary authority to sentence a person to jail for contempt of court, the Supreme Court does not have the authority to remove members of the EC from office. Members of EC can only be removed from office by the parliament on the grounds of misconduct, incapacity or incompetence. ${ }^{56}$

Therefore, it is evident from the provisions of the Constitution, that neither the Supreme Court nor the judiciary has any role in the removal of a member of the EC. It is indeed an absolute authority of the parliament to remove or dismiss members of the EC from office. Therefore, by dismissing both the Commissioner and Deputy Commissioner of the EC from office, the Supreme Court had performed a constitutionally mandated function of the parliament. Therefore it can be established that the action of the Supreme Court ultra vires the Constitution and consequently renders the action unconstitutional.

This ruling by the Supreme Court was criticized by the legal fraternity of Maldives as well as the international community. The European Union Election Observer Mission (EUEOM) criticized the ruling stating that the ruling was 'clearly an intrusion by the judiciary on the role of the parliament and a violation of separation of power." 57 Shamsul Falaah, a licensed advocate of the High Court of Maldives, also wrote regarding the matter that while "there is an understanding that apex courts can issue guidelines for certain circumstances,' especially in instances 'where there is a possibility of a constitutional interregnum or a legal-vacuum', the Supreme Court issuing guidelines despite the enacted 'clear constitutional and legal frameworks' is questionable. ${ }^{58}$

Nevertheless, these concerns were disregarded, and the guidelines set forth by the Supreme Court in Jumhooree Party v. Elections Commission

\footnotetext{
56 Ibid., Article 177 (a) and (b).

${ }^{57}$ International Commission of Jurists (ICJ), 15.

58 Shamsul Falaah, "Abusive Judicial Discretion in the Maldives, Maldives Independent", Maldives Independent, 13 September, 2018.
} 
[2013], was enforced in the 2013 Presidential Elections as well as in the latest Presidential Election held in 2018.

In 2015, the second Suo Motu case by the Supreme Court was initiated against the Human Rights Commission of Maldives (HRCM). In this case, the Supreme Court stated that the HRCM had in its report submitted to the Universal Periodic Review Process of the Human Rights Council, provided incorrect and misleading information regarding the jurisdiction, rules, and procedures of the judiciary. The Supreme Court also expressed that the HRCM had criticized the actions taken by the Supreme Court to ensure the rule of law in the Maldives, based on baseless and false information. Hence, in this case, the Supreme Court declared the report submitted by the HRCM of providing false information regarding the judiciary and undermining the trust vested unto the judiciary by the public. Furthermore, the Supreme Court ordered the HRCM to respect the Constitution of the Republic of Maldives. In this case, the Supreme Court also determined eleven legally binding guidelines, which specifies how the HRCM must conduct its activities to promote and protect human rights in the Maldives. ${ }^{59}$

HRCM, much like the EC, is an independent institution. The functions, powers, responsibilities and duties and such of the HRCM are determined by the Constitution and subsequent legislation enacted by the parliament. ${ }^{60}$ Therefore, it is evident from the provisions of the Constitution, that the Supreme Court does not have the jurisdiction nor the authority to determine guidelines for the HRCM to adhere to in performing its constitutionally mandated functions of promoting and protecting human rights in the Maldives. In fact, by determining the guidelines, the Supreme Court had performed a constitutionally mandated function of the parliament.

This ruling by the Supreme Court against the HRCM also faced international condemnation; the Court's decision was denounced by the UN High Commissioner for Human Rights, the UN Special Rapporteur on the Independence of Judges and Lawyers, the UN Special Rapporteur

\footnotetext{
59 Suo Motu Case Against the Human Rights Commission of Maldives [2015], Supreme Court of Maldives, (Case No.: 2014/SC-SM/42), Supreme Court of Maldives, 16 June 2015.

${ }^{60}$ Constitution of Maldives, 2008, Articles 189 (b) and (c).
} 
on Human Rights Defenders and the President of the UN Human Rights Council, among others. Mainly, the backlash was regarding the Supreme Court's decision to initiate the Suo Motu case against the HRCM; it was deemed as an attempt to undermine and influence the authority of the HRCM to perform its functions. ${ }^{61}$ The international community and the local legal fraternity failed to address the fact that the Supreme Court, has yet again, assumed a constitutionally mandated role of the parliament and undermined the supremacy of the Constitution.

\section{AMENDING AN INCONSISTENCY}

In 2015, the Supreme Court repealed the provisions of the Judicature Act (Act No.: 22 of 2010), Employment Act (Act No.: 2 of 2008), ${ }^{62}$ Tax Administration Act (Act No.: 3 of 2010) and the Right to Information Act (Act No.: 1 of 2014), ${ }^{63}$ which specified the duration for appealing certain matters to appellate courts. The Supreme Court stated that the appeal period provided in these Acts were too long and therefore contradicted with the right of the people to speedy justice.

The Supreme Court did not stop at just declaring the provisions of those legislations void. This ruling by the Supreme Court was followed by a circular issued by the Supreme Court specifying a new appeal period, infringing and assuming the role of the legislature to amend legislation.

As mentioned previously in this article, the Supreme Court does not have the authority to amend the inconsistencies of legislation declared

${ }^{61}$ United Nations Human Rights Office of the High Commissioner, "Maldives: UN Experts Urge Supreme Court to Reconsider Decision Against Human RightsCommission",

<https://www.ohchr.org/EN/NewsEvents/Pages/DisplayNews.aspx?NewsID=16 101\&LangID=E> (accessed 18 September, 2018).

${ }^{62}$ Supreme Court Ruling Issued Regarding Articles 15 and 42 of the Judicature Act and Article 85 (b) of the Employment Act [2015], Supreme Court of Maldives, (Supreme Court Ruling No.: 2015/SC-RU/01) 27 January 2015.

63 Supreme Court Ruling Issued Regarding Article 55 (b) of the Tax Administration Act and Article 64 (a) of the Right to Information Act [2015], Supreme Court of Maldives, (Supreme Court Ruling No.: 2015/SC-RU/02), 17 February 2015. 
invalid or unconstitutional by the Supreme Court. However, the Constitution provides the Supreme Court with the authority to issue an order suspending the declaration of the invalidity of the legislation or provision of the legislation, in order to allow the relevant authority, i.e. the parliament, to amend the inconsistency. However, by issuing a circular specifying a new appeal period, the Supreme Court had amended the inconsistency.

Furthermore, the Constitution grants the parliament with the authority to legislate regarding the judiciary; Article 155 of the Constitution states that the parliament has the power to enact legislation regarding the administration of the Courts of law, the jurisdictions and the procedures of the Courts as well. ${ }^{64}$ Therefore, with this decision, despite the established legal frameworks, the Supreme Court undermined the supremacy of the Constitution and performed a constitutionally mandated function of the parliament.

\section{LIMITING PARLIAMENTARY OVERSIGHT ROLE}

Since the very first Constitution of the Maldives in 1932, the parliament has enjoyed the absolute authority to take no-confidence votes against members of the Cabinet. The new democratic Constitution of 2008 also vests this absolute authority unto the parliament; Article 101 (d) of the Constitution specifically states that any member of the Cabinet, against whom a no-confidence vote is passed by the parliament would immediately be removed from office. ${ }^{65}$

Despite the simple and clear language of this provision of the Constitution, in 2017 the Attorney General requested the Supreme Court to determine a guideline for the parliament to adhere to when taking votes of no confidence against members of the Cabinet, in order to avoid baseless political decisions by the parliament. In this case, the Supreme Court expressed that the premise of the request by the Attorney General is to interpret Article 101 of the Constitution, which specifies the procedure of taking no-confidence votes against members of the Cabinet.

\footnotetext{
${ }^{64}$ Constitution of Maldives, 2008., Article 155.

${ }^{65}$ Ibid., Article 101 (d).
} 
In its interpretation of Article 101 of the Constitution, the Supreme Court stated that the authority to take no confidence votes should be interpreted in the manner it would be interpreted in a presidential system in which there is an absolute separation of powers. The Supreme Court stated that, if the parliament arbitrarily acted upon the provisions of the Constitution that provides the parliament the authority to remove public officials from office, it would directly affect the constitutional functionality of the government and the fundamental rights of the people. Therefore, in this case, the Supreme Court determined that, the validity of any noconfidence vote taken by the parliament against not only the members of the Cabinet, but the President, Vice President, ${ }^{66}$ Judges, ${ }^{67}$ members of the $\mathrm{EC},{ }^{68}$ members of the Civil Service Commission (CSC), ${ }^{69}$ members of the $\mathrm{HRCM},{ }^{70}$ members of the Anti-Corruption Commission (ACC), ${ }^{71}$ Auditor General ${ }^{72}$ and the Prosecutor General ${ }^{73}$ would be determined by the Supreme Court. ${ }^{74}$

With this decision, the Supreme Court limited a constitutionally vested authority of the parliament. This decision is conflicting since the parliament only has the authority to remove judges of the Supreme Court from office. The authority to appoint and remove all other Judges of Courts of law in the Maldives is vested unto the Judicial Service

${ }^{66}$ Ibid., Article 100; specifies the procedure through which the parliament can impeach the President and or the Vice President.

${ }^{67}$ Ibid., Article 154 (b); specifies the procedure through which the parliament can remove a Judge from office.

${ }^{68}$ Ibid., Article 177; specifies the procedure through which the parliament can remove a member of the Elections Commission from office.

${ }^{69}$ Ibid., Article 187; specifies the procedure through which the parliament can remove a member of the Civil Service Commission from office.

${ }^{70}$ Ibid., Article 197; specifies the procedure through which the parliament can remove a member of the Human Rights Commission from office.

${ }^{71}$ Ibid., Article 207; specifies the procedure through which the parliament can remove a member of the Anti-Corruption Commission from office.

72 Ibid., Article 218; specifies the procedure through which the parliament can remove the Auditor General from office.

${ }^{73}$ Ibid., Article 228; specifies the procedure through which the parliament can remove the Prosecutor General from office.

${ }^{74}$ Petition to Supreme Court Regarding Constitutional Matter (No Confidence Votes against Cabinet Ministers) by Attorney General's Office [2017] Supreme Court of Maldives, (Case No.: 2017/SC-C/11), 22 May 2017 
Commission (JSC). The Supreme Court bench declaring the validity of the parliament's vote to remove a Supreme Court Judge would immediately become a matter of conflict of interest. Furthermore, the authority to take no-confidence votes against all of the above is vested unto the parliament by the Constitution, through its constitutional provisions. This constitutionally vested authority can only be limited by amending the Constitution; a function only the parliament is constitutionally authorized to perform.

\section{COURT RULING ON FLOOR-CROSSING}

Another controversial ruling issued by the Supreme Court in 2017, was the ruling issued regarding the floor-crossing of members of the parliament. In this case, the Attorney General requested the Supreme Court to determine a procedure through which members of parliament who defects from their political party, or members who defect to another political party or members who are removed by the political party, would immediately lose their seat in the parliament. Although the fact of the matter is, along with the qualifications required of members of parliament, in Article 73 (c) of the Constitution does specify the grounds on which members of parliament would lose their seat in the parliament. The Article specifies that a candidate contesting in the parliamentary election or a member of parliament would be disqualified if the person has a decreed debt which is not being paid as provided in the judgment. The Article also states that the person would be disqualified if the person is convicted of a criminal offense and is serving a jail sentence of more than twelve months. Furthermore, if the member is also a member of the judiciary, i.e. a judge, the Article specifies that the person would also be disqualified. ${ }^{75}$

Therefore, there is an established constitutional framework. The Supreme Court does not have the authority to amend the Constitution or limit the powers vested unto the authorities by the Constitution. The Constitution vests the parliament with the power to amend the Constitution and limit the powers vested to the authorities through legislation enacted by the parliament. Therefore, the Supreme Court does not have the authority to limit or amend the established constitutional

${ }^{75}$ Constitution... 2008, Article 73 (c). 
frameworks. It becomes evident that the Supreme Court is aware of this fact when in the decision of this case, the Supreme Court acknowledged the fact that such a procedure should be enacted by the parliament. However, the Supreme Court determined a temporary procedure for relevant authorities to enforce until a legislation regarding the floorcrossing of members of parliament was enacted by the parliament. ${ }^{76}$ This temporary procedure determined by the Supreme Court resulted in the removal of 12 members of parliament from their seats in the parliament.

It is evident from this decision of the Supreme Court, that even though the Court is aware of the legislative authority of the parliament, the Court had no trouble encroaching on that legislative authority and undermined the supremacy of the Constitution.

\section{SUPREME COURT ORDER ISSUED ON 01 ${ }^{\text {st }}$ FEBRUARY 2018}

The Supreme Court Order issued on $1^{\text {st }}$ February 2018 is possibly the epitome of the Supreme Court's assumption of the legislature's role and the undermining of the supremacy of the Constitution.

In this Court Order issued on its own initiative, the Supreme Court stated that having reviewed the current situation of Maldives, the Supreme Court has found the actions of the Government to be in contradiction with the public interest and the constitutional system of the Maldives. The Supreme Court addressed the temporary procedure established by the Court regarding the floor-crossing of the members of parliament, and since the parliament had not enacted an Anti-Defection Act, the Supreme Court declared the temporary procedure invalid and also declared that the members who lost their seats in the parliament as a result of that temporary procedure, to be reinstated to their positions.

In this Court Order, the Supreme Court also interpreted Article 159 (a) of the Constitution, which provides that the Judicial Service Commission (JSC) is given the authority to investigate and review complaints made against judges. The Supreme Court determined that the provision does not apply to the Chief Justice and the judges of the

\footnotetext{
${ }^{76}$ Petition to Supreme Court Regarding Constitutional Matter (Floor-Crossing of Members of Parliament) by Attorney General's Office., Petitioner, [2017] Supreme Court of Maldives, (Case No.: 2017/SC-C/17), 13 July 2017.
} 
Supreme Court. Therefore, the Supreme Court declared that the JSC does not have the authority to review and investigate any case or complaint filed against the Chief Justice and any Judge of the Supreme Court.

The Supreme Court also declared, as the highest authority in administering justice in the Maldives, that the appointment of judges to Courts of law should be solely under the jurisdiction of the Supreme Court. And therefore, the Supreme Court declared that Judges can only be appointed to any Court of law by an independent institution or any person after having received written approval from the Supreme Court.

Furthermore, in this Court Order, the Supreme Court ordered the immediate release of nine individuals, cases of whom are at different legal stages; some of these individuals' cases had been determined by the Supreme Court while some of these individuals had ongoing court proceedings at lower courts and others were remanded for police investigation purposes without a case filed against them. The different legal stages of these individuals and the application of a retroactive decision by the Supreme Court were cited as a problem with the implementation of the Order by the Attorney General and the Prosecutor General.

In this Court Order, by declaring that the appointment of Judges to Courts of law should be solely in the jurisdiction of the Supreme Court, the court had undermined the supremacy of the Constitution, and limited the constitutionally vested authority of the JSC to appoint Judges to Courts of law. In Article 148 (b) of the Constitution, it is specified that all judges, except the judges of the Supreme Court and the High Court, would be appointed by the JSC. ${ }^{77}$ This constitutionally vested authority and function of the JSC can only be limited by the parliament by amending the Constitution or enacting a law. Furthermore, this decision of the Supreme Court was upheld on $25^{\text {th }}$ July $2018 .^{78}$

The JSC is an independent institution established by the Constitution. The functions, powers, duties and such of the JSC are determined by the

\footnotetext{
77 Ibid., Article 148 (b).

${ }^{78}$ Petition to Supreme Court Regarding Constitutional Matter (Supreme Court Ruling 2018/SC-SJ/01) by Attorney General's Office., Petitioner, [2018] Supreme Court of Maldives, (Case No.: 2018/SC-C/06), 25 July 2018.
} 
Constitution and the legislation enacted by the parliament. ${ }^{79}$ The Constitution entrusts the JSC with the responsibility to appoint, promote and transfer judges other than the Chief Judge and judges of the Supreme Court. However, the JSC does have a role in the appointment of the Chief Justice; providing consultancy to the President when the President determines a nominee for the position of the Chief Justice. ${ }^{80}$ The role of the JSC in the appointment of the Judges of the Supreme Court is evident from the Constitution as well. The President appoints judges to the Supreme Court, after consulting with the JSC, and after having received confirmation from the parliament. ${ }^{81}$

This Court Order issued on $01^{\text {st }}$ February 2018, also the Supreme Court determined that since the Chief Justice and the judges of the Supreme Court are not appointed by the JSC, the institution does not have the authority to review and investigate any matter or complaint filed against the Chief Justice and the Judges of the Supreme Court. However, in Article 159 of the Constitution, it is specified that the JSC has the power to investigate complaints about the judiciary, and to take disciplinary action against them, including providing recommendations to the parliament for the dismissal of judges of the Supreme Court from office. $^{82}$

Therefore, it is clear that the JSC's authority to review and investigate complaints filed against members of the judiciary does, in fact, apply to the Chief Judge as well as the other judges of the Supreme Court. The fact of the matter is the Supreme Court does not have the authority to limit these constitutionally vested powers of the JSC, as it is a function only the legislative branch has the authority to perform.

However, the local legal fraternity and the international community called on for the enforcement of this Court Order. They mainly focused on the part of the Court Order, which overturned the temporary procedure for removal of members of parliament who defect from and or to another political party and the part which ordered the immediate release of the nine individuals. The opposing political parties welcomed

\footnotetext{
${ }^{79}$ Constitution of the Republic of Maldives, 2008., Article 157 (b) and (c).

${ }^{80}$ Ibid., Article 147.

${ }^{81}$ Ibid., Article 148 (a).

${ }^{82}$ Constitution of the Maldives, 2008., Article 159 (a) and (b).
} 
the Court Order issued on $01^{\text {st }}$ February $2018,{ }^{83}$ while the international community called on for the enforcement of this Order; India stated that, "in the spirit of democracy and rule of law, it is imperative for all organs of the Government of Maldives to respect and abide by the order of the apex court", ${ }^{84}$ while the United States of America also expressed that, "the Maldivian government and military must respect the rule of law, freedom of expression, and democratic institutions." 85

Regarding the challenges faced by the Attorney General and the Prosecutor General in implementing the Supreme Court Order issued on 01st February 2018, President Abdulla Yameen Abdul Qayyoom conveyed the concerns to the Supreme Court, in which the President highlighted that the Supreme Court Order, "has resulted in an encroachment on the regulatory powers of the State, the disruption of the functions mandated to State institutions under the Constitution". ${ }^{86}$ And in response to a press release issued by the Government of India, in a statement released by the Ministry of Foreign Affairs, the Government expressed that enforcing the Supreme Court Order issued on $1^{\text {st }}$ February 2018, "would have potentially lead to an undermining of the supremacy of the Constitution." 87

${ }^{83}$ The Associated Press, "Ruling by Court in Maldives Breathes New Life into Political Opposition", New York Times, 1 February, 2018.

${ }^{84}$ Amit Ranjan, "Political Turmoil in Paradise: The Unfolding of the Maldivian Crisis", ISAS Brief, <https://www.isas.nus.edu.sg/wpcontent/uploads/2018/03/ISAS-Briefs-No.-553-Political-Turmoil-in-

Paradise.pdf $>$ (accessed 18 September, 2018), 5.

85 Ibid.

${ }^{86}$ Ministry of Foreign Affairs, "President Shares His Concerns with the Supreme Court in Implementing the Court's Orders", <https://foreign.gov.mv/index.php/en/mediacentre/news/4334-president'sspeeches-vice-president's-speeches-photo-gallery-video-gallery-home-pressoffice-press-releases-president-shares-his-concerns-with-the-supreme-court,-inimplementing-the-court's-orders> (accessed 18 September, 2018).

${ }^{87}$ Ministry of Foreign Affairs, "The Government of Maldives' Decisions are Made in the Best Interest of the Maldivian People", <http://www.foreign.gov.mv/index.php/en/mediacentre/statements/4382-thegovernment-of-maldives'-decisions-are-made-in-the-best-interest-of-themaldivian-people> (accessed 18 September, 2018). 
Eventually, the parts of the Supreme Court Order issued on $1^{\text {st }}$ February 2018 that declared that the JSC does not have the jurisdiction to investigate and review any matter filed against the Chief Justice and the Judges of the Supreme Court and the part that ordered the immediate release of nine individuals was overturned by the Supreme Court Ordered issued on $06^{\text {th }}$ February 2018. ${ }^{88}$ And the part of the Supreme Court Order issued on $1^{\text {st }}$ February 2018 regarding the floor-crossing issue was also overturned by the Supreme Court by a later Supreme Court ruling issued on $25^{\text {th }}$ July $2018 .^{89}$

\section{ASSERTION OF JUDICIAL SUPREMACY}

The purposes of the doctrine of separation of powers are mainly to avoid the concentration of power in one branch of government and to avoid abuse of power..$^{90}$ These purposes, however, are achieved when the constitutions define and apply the doctrine of separation of powers with regards to the purposes it sets out to achieve. In order to achieve these purposes, and to avoid political conflict between these branches of government, and the usurpation of the powers of other branches, the constitution should be clear and concise, in establishing and separating these branches as well as in providing these branches with powers and in specifying their functions. ${ }^{91}$

From the above-mentioned decisions of the Supreme Court, the assertion of the judicial supremacy over the established supremacy of the Constitution is evident. Despite the constitutional provisions, the Supreme Court proceeds to encroach on the constitutionally vested powers of the parliament and perform the constitutionally mandated functions of the parliament. In constitutional democracies, the three branches of government are separated by the Constitution; the powers and functions of those branches are provided in the fundamental principles that govern the country. The courts are entrusted with the responsibility of upholding the supremacy of the constitution and

\footnotetext{
${ }^{88}$ Supreme Court Order Issued on $06^{\text {th }}$ February 2018 [2018], Supreme Court of Maldives, (Supreme Court Order No.: 2018/SC-SJ/03), 06 February 2018.

${ }^{89}$ Petition to Supreme Court (Case No.: 2018/SC-C/06), 25 July 2018.

${ }^{90}$ Kavanagh, The Constitutional Separation of Powers, 222.

${ }^{91}$ Glassman, Separation of Powers: An Overview, 1.
} 
protecting the constitution. However, in constitutional democracies, it is common for the Judiciary to test the boundaries of the Constitution, usurp the powers of the other branches of government, all the while performing their constitutionally mandated function of judicial review. ${ }^{92}$ The Judiciary often forgets that the branch itself is established by the Constitution, and derives its powers from the Constitution, as well.

The Constitution of the Republic of Maldives does not allow the judiciary to enact, amend or repeal laws in any form. The scope of the judiciary's authority to judicial review is simple; declaring legislations and regulations inconsistent with the Constitution as being invalid. There are limitations imposed on the authority to conduct judicial review as well, whereby the judiciary does not have the authority to amend an inconsistency found in the said legislation or regulations, but does have the discretion to issue an order suspending the declaration of the invalidity of the legislation or regulation to allow the parliament to amend the inconsistency. Aside from that, even though the judiciary has the authority to interpret the Constitution, the judiciary does not have the authority to regulate and impose limitations based on its interpretations. The Supreme Court also does not have the authority to limit or perform constitutionally mandated functions from the other branches of the government.

\section{CONCLUSION}

Since the branches of government are established and separated by the Constitution and derives their powers from the Constitution, it is evident that the branches of government are indeed not above the Constitution. The supremacy of the Constitution is established to ensure the separation and the independence of the branches of government, to perform its constitutionally mandated functions. Mechanisms of checks and balances are instilled in the Constitution to 'help to protect the separation' of each branch and 'to ensure that each branch does not overstep its role in the constitutional scheme. ${ }^{93}$

\footnotetext{
${ }^{92}$ Phineas M. Mojapelo, "The Doctrine of Separation of Powers (a South African Perspective)", Advocate (General Council of the Bar of South Africa), vol. 26. no. 1 (2013): 38.

${ }^{93}$ Kavanagh, The Constitutional Separation of Powers, 234.
} 
The legal fraternity is divided on the issue of enforcing a Supreme Court ruling, decision or Order that encroaches on the constitutionally mandated functions of other branches of government, and the boundaries of the Constitution. The enforcement of such decisions by the Supreme Court inevitably leads to the undermining of the Constitution. When the supremacy clause of the Constitution is considered, such decisions by the Supreme Court encroaching on the other branches of government as well as undermining the supremacy of the Constitution, must not and cannot be enforced. This is because such decisions or parts of such decisions are in fact in contradiction with the Constitution. In accordance with the supremacy clause of the Constitution, any order, or decision or conduct, which contradicts with the Constitution, is void. The Supreme Court is established by the Constitution. The powers and functions of the Supreme Court are determined by the Constitution and subsequent legislation enacted by the parliament. The Supreme Court is at the top of the hierarchy of the judiciary but it is definitely not above the Constitution.

The solution to upholding the supremacy of the Constitution is simple. The solutions are upholding the rule of law, enforcing the Constitution to the letter, and exercising restraint in performing their constitutionally mandated functions. The three branches of government, the legislative, executive and the judiciary, have to recognize the different roles, which the Constitution grants them, and respect the 'sphere of action of the other'. In performing the constitutionally mandated functions of each branch, they should exercise restraint, to ensure that they are within their jurisdiction and to ensure that they are not encroaching on each other's jurisdiction. ${ }^{94}$

Evidently, there is a political factor that determines the decisions of the Supreme Court to undermine the supremacy of the Constitution. Even though there are clear constitutional provisions, through its interpretation of the legislation and through its power to judicial review, the Supreme Court evidently plays a key role in politics. The political conflict generated by the constitutional structure of separation of powers results

${ }^{94}$ Ibid., 236. 
in a constant struggle for each branch to expand their authority and exert their influence on other branches of the government. ${ }^{95}$

In the Maldives, in order to gain the preferred political result, it could be perceived that the politicians approach the Supreme Court for its political decisions. Even though such decisions undermine the supremacy of the Constitution, those decisions provide an easy fix to the problem compared to the legislative process of the parliament.

${ }^{95}$ Glassman, Separation of Powers: An Overview, 12. 